\title{
GCU
}

Glasgow Caledonian

University

University for the Common Good

\section{State ownership, institutional effects and value creation in cross-border mergers \& acquisitions by Chinese firms}

Du, Min ; Boateng, Agyenim

Published in:

International Business Review

DOI:

10.1016/j.ibusrev.2014.10.002

Publication date:

2015

Document Version

Early version, also known as pre-print

Link to publication in ResearchOnline

Citation for published version (Harvard):

Du, M \& Boateng, A 2015, 'State ownership, institutional effects and value creation in cross-border mergers \& acquisitions by Chinese firms', International Business Review, vol. 24, no. 3, pp. 430-442.

https://doi.org/10.1016/j.ibusrev.2014.10.002

\section{General rights}

Copyright and moral rights for the publications made accessible in the public portal are retained by the authors and/or other copyright owners and it is a condition of accessing publications that users recognise and abide by the legal requirements associated with these rights.

Take down policy

If you believe that this document breaches copyright please view our takedown policy at https://edshare.gcu.ac.uk/id/eprint/5179 for details

of how to contact us. 


\title{
Glasgow Caledonian University
}

\section{State Ownership, Institutional Effects and Value Creation of Cross-border Mergers \& Acquisitions by Chinese Firms}

\author{
Du, Min ; Boateng, Agyenim
}

Published in:

International Business Review

DOI:

10.1016/j.ibusrev.2014.10.002

Publication date:

2015

Document Version

Early version, also known as pre-print

Link to publication in ResearchOnline@GCU

Citation for published version (APA):

Du, M., \& Boateng, A. (2015). State Ownership, Institutional Effects and Value Creation of Cross-border Mergers \& Acquisitions by Chinese Firms. International Business Review, 24(3), 430-442. 10.1016/j.ibusrev.2014.10.002

\section{General rights}

Copyright and moral rights for the publications made accessible in the public portal are retained by the authors and/or other copyright owners and it is a condition of accessing publications that users recognise and abide by the legal requirements associated with these rights.

- Users may download and print one copy of any publication from the public portal for the purpose of private study or research. - You may not further distribute the material or use it for any profit-making activity or commercial gain

- You may freely distribute the URL identifying the publication in the ResearchOnline@GCU portal

If you believe that this document breaches copyright please contact us at: repository@gcu.ac.uk providing details, and we will remove access to the work immediately and investigate your claim. 


\section{State Ownership, Institutional Effects and Value Creation of Cross-border Mergers \& Acquisitions by Chinese Firms}

\section{Introduction}

Cross-border mergers \& acquisitions (CBM\&A) activities from emerging market economies have paralleled their home countries economic reforms and integration into the world economy (Aybar and Ficici, 2009). This is in sharp contrast to the past when firms from developed countries have dominated the global market for corporate control and emerging economies were only recipients for these investments. For example, the value of Chinese CBM\&As purchase which stood at $\$ 185$ million dollars in 1991 has risen up to $\$ 34,355$ million in 2011 (UNCTAD, 2012). The rise in outward CBM\&As is partly attributed to market reforms as previous institutional arrangements in emerging market economies did not facilitate economic exchange and competition in the global market (Spicer et al., 2000; Rondinelli and Behrman, 2000). Institutions which are defined as "the rules of the game" help shape the structures, influence strategic choices and competitiveness of firms (North, 1990; Fligstein, 1996). Prior studies in the context of China have documented the effects of institutional pressures and constraints on firms' strategic choices and financing (Cai, 1999; Hitt et al., 2004; Tsui et al., 2004; Hsiang-Chun and Bo, 2012). Institutions within an economy is to reduce both transaction and information costs by reducing uncertainty, establish a stable structure that facilitates interaction and allow firms to improve firm value and move beyond institutional barriers (see Oliver, 1991). DiMaggio (1984); North (1990) echo similar views and indicate that institutional norms shape the nature of economic activity, motivate the behaviour of firms and their firm value. Yet, despite the massive economic and institutional reforms in China, we know very little regarding the effects of Chinese institutions on firm firm value. 
No systematic study using a broad range of institutional variables has been carried out and prior studies have been limited to the effects of state ownership on firm value with inconclusive results (see Sun and Tong, 2003; Tian and Estrin, 2008; Cui and Jiang, 2012). The role played by the home country institutions in shaping international expansion behaviour have implications for firm value in that they affect the cost of doing business, firms' confidence and create individual winners and losers in the marketplace (Kofele-Kale, 1992, Leone, 1986; Boddewyn and Brewer, 1994). Good institutions provide effective functioning of the market mechanisms enabling firms and individuals "to engage in market transaction without incurring undue costs or risks" (Meyer, Bhaumik and Peng, 2009:63; North, 1990) which is essential for firm's value (Shleifer and Vishny, 1994). This is because good institutions facilitate international transactions such as CBM\&As whereas "bad" institutions act as a tax by increasing the cost of doing business (Ang and Michailova, 2008). In this study, we examine the effects of state ownership, home and host country institutions on the firm value of CBM\&As by Chinese firms.

We advance the institutional perspective to examine the effect of state ownership and institutional factors on firm value for a number of reasons: Institutions have huge impact on emerging market firms' behaviour in that government and societal influences are stronger in emerging market economies such as China and India compared to those in developed countries (Hoskisson et al., 2000). One of the key objectives of enterprise reforms in China and the 'go abroad' strategy (a national policy encouraging overseas investments by Chinese firms) initiated in 1999 is to reduce institutional constraints and help Chinese firms to become global champions. After two decades of market reforms and streamlining the outward investment institutions in China, it is appropriate we ask: to what extent do the institutions in 
China increase corporate value? Second, Hitt et al. (2004) indicate that Chinese government's authority over businesses is pervasive, institutional constraints and incentives are the bases for Chinese firms M\&A decisions. State ownership unavoidably brings political objectives into corporate decision-making which can damage corporate value (Shleifer and Vishny, 1994). On the other hand, it is argued that state ownership of firms in China lead to preferential treatment from the government and favourable allocation of resources thereby enhancing the value of a firm. In order to address the relationship between state ownership, institutional variables and firm value, we focus on short-term acquirers' returns as it is a direct measure of shareholder value which is consistent to the strategic goal of wealth maximisation of a firm (McGee, Thomas and Wilson, 2008). Moreover, acquirers' returns measure the future expectations of investors. The results from the examination of firm's share prices over a period of time therefore represent the optimum criterion for measuring corporate value.

The focus of Chinese CBM\&As as an empirical context to study the effects of institutional factors on firm value is motivated by the fact that: i) China is the largest emerging economy and CBM\&A is growing exponentially and constitute a predominant foreign direct investment (FDI) entry strategy by Chinese firms to enter overseas markets (UNCTAD, 2012); ii) although Chinese economy has become diverse and plural (Rugman and Li, 2007), state-owned and -controlled firms remain the dominant force in the CBM\&A activities (Chen and Young, 2010). The prevalence of state ownership allows us to capture its effect on firm value; iii) the institutional environment in China is unique, diverse and dynamic which makes it an ideal to test our hypotheses. Chinese CBM\&As are worldwide and the home institutional changes vary across industries. Despite the massive reforms carried by 
Chinese government, the state remains a dominant player and has maintained its ability to reward and discipline firms for their adherence to its directives (Luo, 2000).

The main contributions of this study are twofold. First, it contributes to the institutional theory and its application in international finance research. By so doing, we provide better understanding of firm responses to the institutional pressures. Our study extends the theoretical development to firms which are both structurally affiliated and separated (SOEs and non SOEs) from Chinese institutions - a complete departure from previous studies such as Hsiang-Chun and Bo (2012); Tian and Estrin (2008) which concentrate on the effects of SOEs on firm value.

Second, the study also contributes to empirical research on cross-border investment by emerging economy firms, especially from China. The surge of CBM\&As which is the primary mode of foreign entry has attracted considerable research among strategy and finance academics (Deng, 2009; Rui and Yip, 2008; Boateng, Wang and Yang, 2008). Yet the impact of institutional factors on corporate value is scarcely discussed. Our study addresses this research gap by shedding lights on the impact of state ownership and institutions on value creation of by Chinese acquirers.

The rest of this study is organised as follows. The next part provides a brief theoretical and conceptual background of the study and reviews the prior literature on CBM\&As. This is followed by the hypotheses of the study. We then discuss the data and research methodology used in this study. Following that is the results and discussions. The final section gives a conclusion and implications of the study. 


\section{Theoretical Framework}

Over the past decade, institutional theory has emerged to be one of the most relevant theories when explaining the behaviour of firms in emerging markets (Child and Rodrigues, 2005, Hoskisson et al., 2000; Buckley et al., 2007). Institutional theory suggests that institutional contexts - the combination of formal rules, informal constraints, and their enforcement characteristics create an impetus for action patterns in an organisation. Scott (1995) identified three pillars of institutional framework to encompass regulatory (i.e. existing laws and rules), cognitive (widely shared social knowledge and perceptions in society that are taken for granted), normative (i.e. social norms, values and cultures). These pillars together offer a broad basis to analyse a country's institutional profile. As applied to management and finance research, the institutional based view maintains that firms are shaped by the home and host countries institutional environments. Firms require legitimacy on top of economic efficiency to survive and succeed (Scott, 1995). A firm makes strategic choices based on the interaction between institutions and organisation (Peng, 2002). It is therefore argued that besides the firm and industry level factors, firm needs to consider wider influences from sources such as the state and society when crafting and implementing its strategies to gain competitive advantage. In the context of China, government maintains strong influences on outward FDI activities. In the outward FDI, acquisition-sponsored and supported by state is becoming normal mode which the China-based enterprises enter and penetrate a host country in the world (Child and Rodrigues, 2005). When conducting CBM\&A activities, firms engage in institutional processes in both home and host countries (Rosenzweig and Singh, 1991; Xu and Shenkar, 2002). The institutional pressures encountered in CBM\&A transactions include: First, within the home country, firms are subject to the home government's 
regulatory restrictions on outward investments. For example, home country capital control for outward investments is prevalent in many emerging economies such as China (Cui and Jiang, 2010; Morck et al., 2008). Firms' CBM\&A decisions in China are influenced directly or indirectly by different levels of government, either through FDI incentives and support schemes or the government-administered approval system. The approval system entails costs which can affect the value of the firm. Similarly, host country institutions may also impact on firm's value. Good host country institutions imply strong legal enforceability, which protect the interest of acquisitions parties involved and reduce cost implied by the asymmetric information. In sum, the quality of host and home institutions reduce uncertainties, constraints, cost of doing business and more importantly speed up the process of mergers and acquisitions to avoid the deal becoming hostile thereby leading to value destruction.

The literature also highlights the effects of state ownership on firm value. The state ownership effects come from two channels. One view suggests that state-ownership damages corporate value because of government intervention which may slow down the decision-making process of the firm in an increasing competitive environment. On the contrary, it is argued that state owned firms are more likely to receive preferential treatment from government thereby enhancing their firm value (Blanchard and Shleifer, 2001). China, like other emerging economies, is characterised by active government involvement in business through ownership and regulation (Child and Rodrigues, 2005; Scott, 2002). It is well-documented that Chinese firms engaged in CBM\&As have benefited from government support through value-added tax and favourable financing (UNCTAD, 2005; Xiao and Sun, 2005). Prior literature has examined whether state ownership has beneficial and detrimental effects on Chinese firm value have produced mixed results (see Sun, Tong and Tong, 2002; Wei, Xie and 
Zhang, 2005). We examine whether the institutions in China's emerging market economy enhance or destroy value of Chinese firms engaged in CBM\&As. This study is timely because the "go abroad" strategy initiated by the Chinese government, which actively provides financial and other support mechanisms to Chinese firms, has been a powerful force behind the surge in CBM\&A activities. Moreover, the government 'go abroad' is being pursued on the assumption that these firms will bring in advanced technology, natural resources and managerial know-how that China lacks and help bolster the national economy and enhance national competitiveness which may be at variance with the shareholder value maximisation (Luo, 2001).

Based on above institutional pressures and the Chinese institutional environment, we propose a conceptual model to analyse the impact of institutional variables on the acquirers' returns of Chinese cross-border M\&As (Figure 1). 


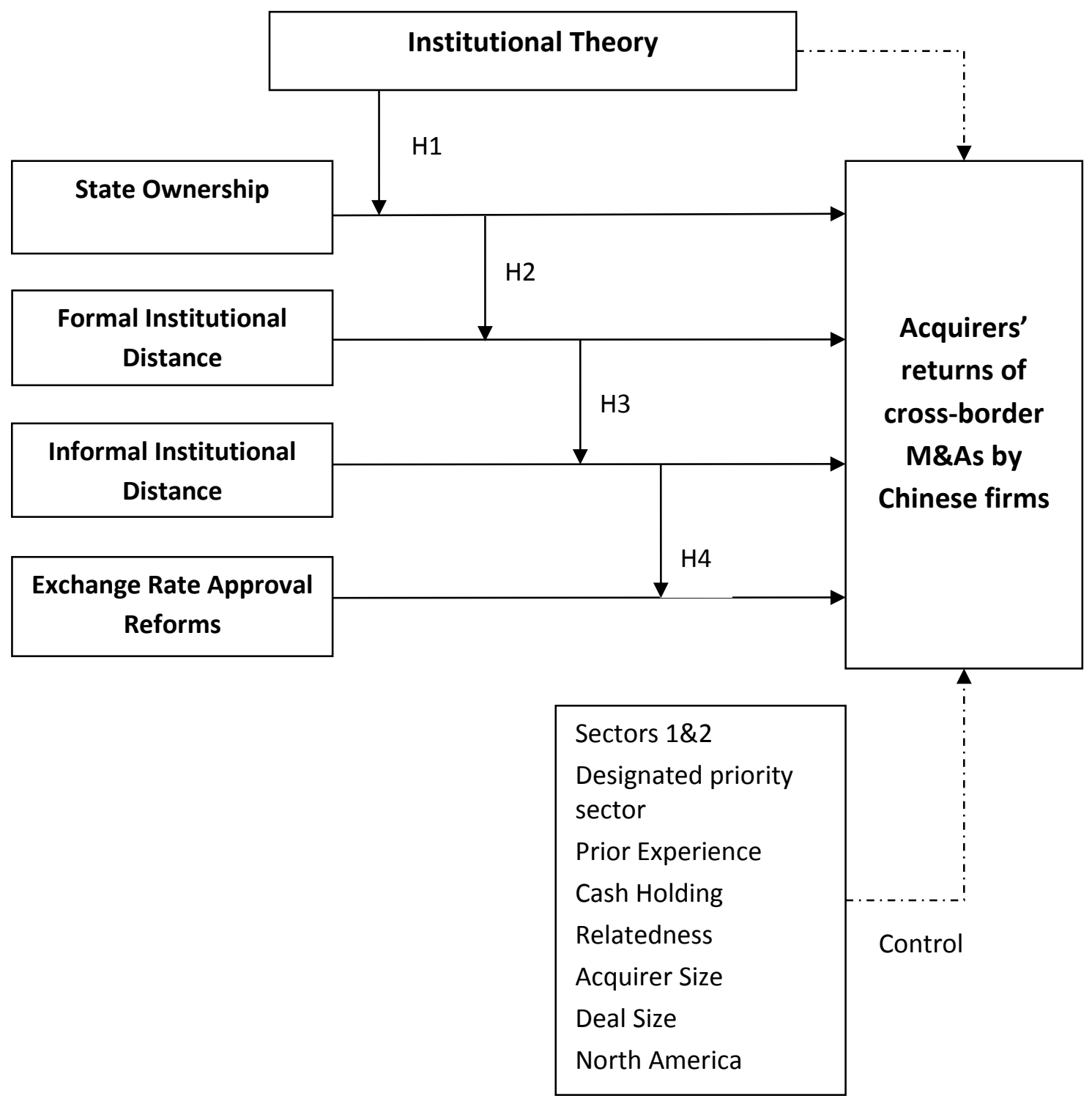

Figure1: Institutional Variables Effect on Acquirers Returns of Chinese cross-border M\&As

\subsection{Hypotheses Development}

\section{State Ownership}

Corporatized State owned firms in China raises a problem of principal-principal governance conflicts in that the government as a shareholder may have different objectives distinct from other shareholders whose primary goal is firm value 
maximisation (Young et al, 2008). A number of scholars, including Walter and Howie (2003), Lau et al. (2007) and Chen and Young (2010), suggest that in China, political motives are central to the strategic decision-making of state-dominated firms rather than purely profit motives. As part of the economic reforms, the Chinese government has pursue a 'go abroad' policy since 1999 with the objectives of securing strategic resources which China lacks and improving Chinese firms' ability to compete on the global stage. The government does so using Chinese firms mostly dominated by the central or local government. Chen and Young (2010) pointed out the pursuit of resource seeking motive or national pride instead of value maximization may have a negative effect on the acquirers' returns. The state-controlled firms are a part of the home country institutions which pursue the state-directed goals such as foreign investment in areas designated as priority by the Chinese government to secure technology and scarce natural material resources which the country lacks and internalise them at home. Therefore, the firm value may not be based on value maximization of shareholders but the extent to which they secure the resources indicated by the state.

On the other hand, it is argued that compared with privately owned firms, firms with state ownership have strong political ties with the government and face less financial constraints. Poncet, Steingress and Vandenbussche (2010) argue that 'political pecking-order' in credit allocation plays an important role in China. Using a data set of 20,000 Chinese firms, they concluded that private firms in China face severe financial constraints on investments while SOEs do not face such constraints. Guarilia, Liu and Song (2011) obtain similar results indicating that SOEs' total assets growth, which encompasses firm investment, is not affected by cash flows. 
In summary, the argument above suggests that firms with large state ownership in emerging economies are not or less subject to financial constraints and these firms still enjoy some degree of soft budget constraints. We argue that the political and economic advantages in terms of preferential treatment given to firms with large government stake may lead to increased firm value. This lead to our first hypothesis:

Hypothesis 1: Acquiring firms with dominant state-ownership will generate positive abnormal returns/value.

\section{Formal Institutional Distance}

Gubbi et al., (2010) argue that the potential for acquisitions to create value for emerging economy acquiring firms would vary across international markets, largely due to the differences in the quality of resources and institutional development in the host country markets where the acquisitions are made. Formal institutions allow firms to engage in market transactions without incurring undue costs or risks with positive effects on firm value (Meyer, Estrin, Bhaumik and Peng, 2009). Explaining this more explicitly, Berry, 2006: 1125) contend that, more institutionally developed markets are likely to provide, inter alia, "location with less risk....where knowledge can be acquired or learned, and to more institutional protection for investments". It follows that acquisitions by emerging economy firms in institutional developed countries, characterised by competitive markets and customer-centric focus, are likely to offer a rich reservoir of learning for Chinese firms which lack cutting edge technology and other resources which can subsequently be internalised in different product markets and at home. Chan, Isobe and Makino (2008) pointed out that the enhanced learning experience offered by targets in more developed institutional environments will be of greater value to emerging economy firms. In a recent study by Gubbi et al., (2010) in 
the context of India, they found a positive relationship between institutional distance and value creation of Indian acquirers. No study has explicitly examined the institutional distance in China, yet China as a former communist country has seen an unprecedented reforms over the past two decades. It would be interesting to examine the impact of institutional distance which captures the regulative and cognitive constructs between two economies on firm value. We therefore hypothesised that:

Hypothesis 2: Chinese acquirers engaged in CBM\&A activities in developed institutional environment will generate positive abnormal returns/value

\section{Exchange Rate Reforms}

Chinese government has attempted to create institutional environment which stimulates and facilitates effective policies towards outward investment, liberalise trade and finance (Wong \& Chan, 2003). The central authorities have also changed foreign exchange regime to a 'buy-to-use' policy in place of 'earn-to-use' policy in early 1990s (Voss, Buckley \& Cross, 2010). The Chinese government employed a simplified application approval process in 2003 with the purpose of providing a speedy and smooth process to firms undertaking overseas mergers and acquisitions. In 2006, central authorities further liberalised regulatory process and foreign exchange control by completely decentralising the system from the State Council to the provincial level with the quota of US $\$ 5$ billion local limit abolished (Wu and Sia, 2002; Voss, Buckley and Cross, 2010). We argue that liberalisation of the exchange reduce bureaucracy and generate positive wealth effect when acquisitions are announced due to potential reduction in the costs of doing business. It is expected that the ensuing efficiencies associated with the reforms in the exchange rate system may 
lead to value for Chinese acquirers on assumption that the stock markets in China are efficient. We therefore test the following hypothesis:

H3: Chinese acquirers engaged in CBM\&As will create more wealth after the reforms in foreign exchange approval systems.

\section{Informal Institutional Distance (Culture)}

Prior literature documents that informal institutions have a significant impact on CBM\&As firm value. It is argued that the cultural proximity improves the firm value of cross-border M\&As by offering access to the acquirers' and targets' diverse set of routines which are embedded in national culture (Hofstede, 1980; Morosini et al., 1998). On the other hand, a number of researchers suggest that significant culture differences between the home country and host country is negatively associated with the firm value of cross-border M\&As and such impact can happen in the preacquisition phase (Hofstede, 1980; Kogut and Singh, 1988) and post-acquisition phase (Geringer et al., 1989). In terms of pre-acquisition culture impact, significant culture differences can be the source of acquired firm management resistance at the time of CBM\&As which can increase the costs of transaction (Cartwright \& Cooper, 1993) and thus lowering the value creation for acquiring firms. In term of post-acquisition, significant culture differences increase the difficulty in post-acquisition assimilation and in the transfer of distinctive competencies between the acquirers and targets (Geringer et al., 1989; Datta and Puia, 1995). Thus, the bigger the culture difference is, the more difficult for acquiring firms to gain normative legitimacy as measured by informal institutions in the host country. One of the main reasons for the failure of TCL of China acquisition of TV Business of Thomson in France was unfamiliarity with the business operations in Europe. According to Peng (2010: 520) "the new 
company did not work well with people from different cultures, with difference experiences, and with different routines." It is argued that, the higher the cultural differences between the two countries, the higher the acquirers' value would be destroyed. Accordingly, the following hypothesis addresses the impact of culture proximity on the acquirers' returns:

Hypothesis 4: High culture distance between China and the target host country has a negative effect on the Chinese acquirers' returns.

\section{Data and Research Methodology}

\subsection{Data Source}

This study considers all completed cross-border M\&As by publicly traded Chinese firms over the period January 1998 to December 2011 from CSMAR of GTA database in HK. For each acquisition, GTA database furnishes information regarding the acquirer name, announcement date, target name, target country of origin, deal value, deal type, restructuring type, industry, and other details. There were several factual errors and missing information in terms of deal value and target country of origin in GTA database and the information was further cross-checked with firm annual report, newspapers, business magazines, and China mergers and acquisitions yearbook. Share price data was also collected from CSMAR of GTA database which provides daily share prices of all the public firms listed in Shanghai Stock Exchange and Shenzhen Stock Exchange. 


\subsection{Sample Selection}

The sample selection procedure for analysing Chinese acquirers' returns begins with the universe of Chinese listed firms conducted cross-border M\&As transactions from January 1998 to December 2011. CSMAR of GTA database reported a total of 1063 cross-border M\&As activities to construct the base set. Table 1 reports how the sample was selected. For inclusion in the final sample, the following restrictions were imposed on the acquiring firms:

(i)

The acquirer must be listed in Shanghai or Shenzhen Stock Exchanges under A share which provides data on CBM\&As in China and the company shares must be actively traded;

(ii) Neither the acquirer nor the target should be a financial firm. All the firms that belong to the financial sectors, such as banks, life assurance, investment firms, insurance and real estate investment trusts are excluded from the sample. The reason behind this is that financial firms have different nature of assets and liabilities, different financial reporting system and its unique regulations which may influence the firm value and biased the results;

(iii) The acquirer must not be involved in multiple acquisitions within three months to separate effects of each acquisition properly;

(iv) There should not be a contaminating announcement within 30 business days before or after the announcement. The reason is that other event around acquisition may also influence the stock price which may lead to biased result of acquisition firm value;

(v) The acquirer must acquire more than $10 \%$ of the target since according to US Department of Commerce, acquiring interest less than $10 \%$ is classified as portfolio investment rather than acquisitive investment with managerial control; 
(vi) The share price data and accounting information of acquirer must be available on CSMAR database.

Table 1: Derivation of Initial Sampling Frame

\begin{tabular}{ll}
\hline Description & Number of CBM\&As \\
& $1998-2011$ \\
\hline Total number of Chinese cross-border M\&As & 1063 \\
Exclude non-listed firms & 7 \\
Exclude non-A shares from Shanghai & 36 \\
Exclude non-A shares from Shenzhen & 43 \\
Exclude financial firms & 15 \\
Exclude multiple acquisitions within 3 months & 156 \\
Exclude contamination event within 30 days prior to and after & 122 \\
acquisition & 199 \\
Exclude acquisitions less than 10\% & 17 \\
Exclude inadequate stock prices 360d before CBMAs & 468 \\
Total usable sample & \\
\hline
\end{tabular}

The imposition of these restrictions led to the final usable sample consisted of 468 cross-border acquisitions by Chinese bidders. It is important to point out that the data from CSMAR database was compared with Thomson SDC Platinum M\&A database and Datastream. CSMAR database appears to provide relatively more up-to-date information in terms of number of acquisitions and stock returns with fewer missing values. To achieve the objective of examining the short-term acquirers' returns in this study, this study adopted event study methodology. The principle behind the event study is to compare the actual return with the normal return which was calculated by market model parameters to analyse acquirers' abnormal returns. In order to get individual firm returns, in line with the past precedent (Gubbi et al., 2010), this study used daily adjusted share prices for each sample firms. Prior literature suggests that 
daily share prices enable scholars to isolate the market's response to a certain event at event date more effectively. The daily data lowers the possibility of biased estimated returns by extraneous events. A sample size of 468 transactions is sufficiently large and hence an assumption of normality, which is a critical concern in event study methodology (Sudarsanam \& Mahate, 2003; Gubbi et al., 2010).

\subsection{Data Analysis}

\section{Event study (Cumulative Abnormal Returns)}

This study used market response to the announcement, i.e. event study to examine the short-term acquirers' returns of Chinese cross-border M\&As. Event study allows researchers to examine whether there are abnormal share prices returns associated with an event. The event date in this study is set to be the announcement data of each M\&As event. According to McWilliams \& Siegel (1997), the most important issue of research design is to determine the length of event window. McWilliams \& Siegel (1997) suggest the length of event window should be short enough to enhance the power of the analysis and sufficiently large to incorporate the full impact of the event. Based on the above argument and the prior studies on cross-border M\&As, this study used a both relatively short event windows $(-1,1 ;-1,3 ;-2,2)$ and two relatively long event windows $(-5,5) ;-10,10)$.

According to Prabhala (1997), the process of data analysis is as follows:

$$
\begin{aligned}
& R_{i, t}=\frac{P_{i, t}}{P_{i, t-1}}-1 \\
& R_{m, t}=\frac{P_{m, t}}{P_{m, t-1}}-1
\end{aligned}
$$


Where $R_{i, t}$ represents the daily return of stock $i$ at day $t$, while $P_{i, t}$ refers the closed price of stock $i$ at day $t . R_{m, t}$ represents the daily return of the market at day $t$, while $P_{m, t}$ refers the closed market index ratio at day $t$.

Then the regression of $R_{i, t}$ to $R_{m, t}$ is accessed, using the data a relatively long period before the announcement day.

$R_{i, t}=\alpha_{i}+\beta_{i} R_{m, t}+\varepsilon_{i}$

Where,

$t=$ day measured relative to event,

$\alpha_{i}=$ estimated period intercept of firm $i$

$\beta_{i}=$ OLS estimates of firm $i$ 's market model parameters of the relationship between $R_{i, t}$ and $R_{m, t}$

$R_{m, t}=$ Shanghai Stock Exchange and Shenzhen Stock Exchange Composite Index (a proxy for the market portfolio of risky assets),

$\varepsilon_{i t}=$ the random error of firm $i$ on the sample event day $t$,

$R_{i, t}=$ return on firm $i$ on day $t$,

The market model is used to estimate the returns on the stock that would have been expected on the event day (the day of acquisition announcement), or during a certain event window around event day if the event had not happen. In this study, this return is estimated by using a 340-day estimation period from $t=-21$ to $t=-360$, where $t=0$ is the event day. 
The abnormal return (AR) due to the acquisition announcement for each firm $i$ on day $t$ thus equals the actual return minus the estimated normal return and is calculated as follows:

$A R_{i t}=R_{i, t}-\left(\widehat{\alpha_{i}}+\overrightarrow{\beta_{i}} R_{m, t}\right)$

Where,

$t=$ day measured relative to event,

$\alpha_{i}=$ estimated period intercept of firm $i$

$\beta_{i}=$ OLS estimates of firm $i$ 's market model parameters of the relationship between $R_{i, t}$ and $R_{m, t}$,

$R_{m, t}=$ Shanghai Stock Exchange and Shenzhen Stock Exchange Composite Index (a proxy for the market portfolio of risky assets),

$R_{i, t}=$ return on firm $i$ on day $t$,

$A R_{i, t}=$ excess return on firm $i$ on day $t$.

Daily abnormal returns are then estimated for each day $t$ for each firm $i$.

In order to see clearly and gain a general insight into the abnormal return observations for a sample of $N$ firms, the daily abnormal return should be replaced by the average abnormal returns (AARs) and the cumulative abnormal returns (CARs). The daily average abnormal return for each day $t$ is calculated as follows: 


$$
A A R_{i, t}=\frac{\sum_{t=1}^{n} A R i, t}{n},
$$

Where $A A R_{i, t}$ is the average abnormal return for the period from $t=$ day 1 until $t=$ day $n$. Since the full effect of an event on firm stock price may not be reflected on a single day, event study often estimates the return for a period around an event, which is called the event window.

In this study, the event window is defined as the period between 20 days prior to the event and 20 days ex post the event. The predicted return on the stock calculated from $A R_{i, t}$ during the event window $(-20,20)$ are compared with the actual stock return observed on each day within the event window and the difference between the actual return and the expected return during the event window is called cumulative abnormal return $(C A R)$. In equation, $C A R_{i, t}$, is estimated by summing average abnormal returns over the event period as follows:

$$
C A R_{i, t}=\sum_{t=1}^{n} A A R_{i, t}
$$

Where $C A R_{i, t}$ is the cumulated abnormal return for the period from $t=d a y 1$ until $t=\operatorname{day} n$.

The cumulative average abnormal returns (CAARs) over the event time, $C A A R_{i, t}$, is estimated as:

$$
\operatorname{CAAR}_{i, t}=\frac{\sum_{t=1}^{n}{ }_{C A R_{i, t}}}{n}
$$


where $C A A R_{i, t}$ is the cumulative average abnormal return over the time period from $t=\operatorname{day} 1$ until $t=$ day $n$.

Individual firm's cumulative abnormal return is standardized by the following equation:

$\operatorname{SCAAR}_{i}\left(D_{1}, D_{2}\right)=\frac{\operatorname{SCAAR}_{i}\left(D_{1}, D_{2}\right)}{S D_{i}}$

Where,

$\left(D_{1}, D_{2}\right)$ is the event window,

$S D_{i}$ is calculated according to

$S D_{i}=S_{i} \sqrt{k+\frac{k}{M}+\frac{\sum_{t=1}^{k} R_{m t}-k\left(\overline{R_{m}}\right)^{2}}{\sum_{t=1}^{M}\left(R_{m t}-\overline{R_{m}}\right)^{2}}}$

Where,

$S_{i}=$ the standard error of the market model regression,

$M=$ the number of observations in the estimation period,

$R_{m t}=$ the return on the market portfolio for day $\mathrm{t}$,

$\overline{R_{m}}=$ the average return of the market portfolio for the estimation period,

$k=$ the number of days in the event window.

A $Z$ statistic is calculated according to

$Z=\frac{1}{\sqrt{N}} \sum_{i=1}^{N} S C A A R_{i}$ 


\section{Cross-sectional Regression of SCARs}

It is well documented in the literature that value creation of CBM\&As is influenced by a number of firm level, industry level and country level factors. The meta-analysis of both domestic and CBM\&As studies indicate that "the wide variance surrounding the association between $M \& A s$ activity and subsequent firm value suggests subgroups of firms do experience significant, positive returns from such activity. Existing models have failed to clearly identify these groups" (King et al., 2004:196) To explain whether Chinese institutions influence the cumulative abnormal returns of Chinese firm which conducted CBM\&As, we use the following regression model:

$\operatorname{SCAR}(-5,5)=\beta_{0}+\beta_{1}($ StateOwn $)+\beta_{2}($ FInsDis $)+\beta_{3}($ CInstDis $)+$

$\beta_{4}($ ExRate $)+\varepsilon$

\section{Control Variables}

Following the M\&A literature, several control measures were included in the regression model. First, we control the sectors in line with the study of Doukas and Travlos (1988), who reported wealth gains across different sectors. We used two dummy variables to control the influences of manufacturing and primary sectors. The prior experience of the Chinese acquirer conducting M\&A activity overseas may influence the firm's perceived risk and uncertainty as well as the willingness to commit resources and consequently the firm value. Standard corporate finance theory describes a common corporate governance problem whereby management excessively retains earnings and invests them into low-return projects to build corporate empires. For example, substantial cash holdings could serve managers' personal interests because large holdings of cash could lead managers to invest unproductively (Jensen, 
1986) or to undertake value-decreasing acquisitions (Hartford, 1999). We expect the cash holdings of the acquiring firm to have impact on the firm value. Acquirer size indicates the firm's capability to generate gains through the economies of scale and scope, and consequently the higher returns for acquirers (King et al., 2004; Moeller et al., 2004). Asquith et al., (1983), and Houston and Ryngaert (1994), find that the average wealth gains to the bidders increase significantly as target size increases. We therefore include deal size as a control variable. Acquisition relatedness may create market power for the acquiring firm by increasing the absolute size and breadth of the firm (Singh and Montgomery, 1987) and consequently enhancing firm value through economies of scale. Prior studies suggest that regional domicile have impact on value creation of acquirers (Kiymaz, 2004; Aybar and Ficci, 2009). Accordingly, we include three dummy variables for North America, Europe, and Asia to control the effects of the geographical origin of target. CBM\&As by Chinese firms are primarily motivated by market development and to obtain foreign advanced technology and natural resources (Boateng, Wang and Yang, 2008: Deng, 2008). The Chinese government, through its "go abroad" policy, has classified some sectors as strategic"; these sectors receive more active support, and firms that conform to the direction of government policies can more readily access inputs, such as cheaper sources of funds, and other incentives. We expect firms investing in priority sectors to obtain more preferential treatment thereby invoking a favourable response from the markets. In

\footnotetext{
${ }^{1}$ In recent years, an expressed goal of state-directed Chinese overseas direct investment has been to access advanced proprietary technology; natural resources and other immobile strategic assets and other capabilities (Deng, 2003; Cai, 1999; Wu and Sia, 2002). The Chinese government provides support in the form of information on obstacles and problems encountered by OFDI firms, lower lending rate credit funds for companies engaged in acquisitions for the following: i) energy; natural resources in mining, gas and oil, textiles; and transport and communication manufacturing. The priority sector in this study include: minerals, petroleum, fishery, agriculture products, textiles; motor, communication equipment manufacturing.
} 
order to account for this distinct possibility, we collated additional data in respect of priority sectors. We therefore control priority sector using a dummy variable.

Our second regression equation is as follows:

$$
\begin{aligned}
& \operatorname{SCAR}(-5,5)= \\
& \beta_{0}+\beta_{1}(\text { StateOwn })+\beta_{2}(\text { InsDis })+\beta_{3}(\text { CInstDis })+\beta_{4}(\text { ExRate })+ \\
& \beta_{5}(\text { PriorSec })+\beta_{6}(\text { Sector } 1)+\beta_{7}(\text { Sector })+\beta_{8}(\text { Experience })+\beta_{9}(\text { CashHld })+ \\
& \beta_{10}(\text { DSize })+\beta_{11}(\text { LAcqSize })+\beta_{12}(\text { Relatedness })+\beta_{13}(\text { NAmerica })+ \\
& \beta_{14}(\text { Europe })+\beta_{15}(\text { Asia })+\varepsilon
\end{aligned}
$$

\section{Variables Measurement}

Cumulative Abnormal Returns (CARs)

We employ stock market reaction to the announcement, as reflected in the firm's share price movement around the announcement of the M\&A event. We chose shareholder wealth creation for the following reasons: i) it is widely accepted in finance literature that the goal of a firm is to maximise the wealth of its shareholders, which is measured by stock prices, and prior studies in finance and strategic management have extensively used market reaction in M\&A studies (see Delong, 2001; Sudarsanam and Mahate, 2003; McGee, Thomas and Wilson, 2005); ii) Haleblian, Kim and Rajagopalan (2006) and Kale, Dyer and Singh (2002), point out that share price movement has a better predictive validity than other objective measures such as profitability, in that it is an ex-ante firm value measure that has been found to correlate with ex-post firm value; and iii) share price movement is relatively 
unbiased compared to other measures and invariant to differences in accounting policies across nations (Cording, Christmann and King, 2008). We measure the M\&A short-term firm value of Chinese acquirers using the standardised cumulative abnormal returns (SCARs) for the event window $-5,5$ period.

The manner in which the independent variables are measured is shown in Table 2.

Table 2: Definition of Independent Variables

\section{Definition}

Expected

Effect

\section{State Ownership \& Institutional Variables StateOwn \\ (State Ownership)}

\section{InsDis}

(Formal Institutional distance)

\section{ExRate}

(Exchange Rate Reforms)
Percentage of equity ownership to total equity by the central government, local government, and its agencies, institutions held in a Chinese firm (Lin et al., 1997; $\mathrm{Xu}$ and Zhang, 2008). Data on firm ownership stakes were collected from CSMAR database.

Differences in the institutions between the two economies using International Country Risk Index. For each target country in our sample, we divide the value for selected indicator for that year by a corresponding value for China, and take the mean across the indicators such as democratic accountability, government stability, investment climate, corruption, law and order, bureaucratic quality to obtain the final value. Values $>1$ signify higher and those $<1$ reflect lower levels of institutional development relative to China (Gubbi et al., 2010)

A dummy variable representing exchange rate reforms policy is constructed. Indicator equals 1 if the CBM\&A transaction is conducted during the period 1998-June, 2006 with fixed exchange rate policy, and afterwards when the foreign currency approval 
system for outward investment was abolished.

CulDis

(Culture Distance)

\section{Control Variables}

Sector 1

Sector2

Experience

(Prior Experience)

\section{Relatedness}

DSize

(Deal Size)

\section{LAcqSize}

(Log of Acquirer's total assets)

CashHld

Cashholding

NAmerica

(North America)

Europe

Asia
We use a cultural distance index based on Hofstede's culture dimensions, namely, power distance, individuality, masculinity, uncertainty avoidance and long-term orientation (long-term orientation excluded from calculation for lack of data). For each target country in our sample, we divide the value for the selected cultural index category for that year by corresponding value for China and taking the mean across the four ratios thus obtained as the final value. Values $>1$ signify higher and those $<1$ reflect cultural proximity (Gubbi et al., 2010).

Dummy variable indicating

Manufacturing sector $=1 ; 0=$ otherwise 1 = firms from Primary sectors, 0 $=$ otherwise

Number of prior foreign acquisitions made at the time of purchase

$+/-$

$+/-$

$+$

$+$

A dummy variable taking the value 1 if acquirer and target are in similar business and 0 otherwise

Log of the amount paid for the target in Chinese Yuan

Log of acquirers' total assets in Chinese +Yuan

Ratio of cash and cash equivalents to total assets.

Dummy variable indicating North

America $=1 ; 0=$ otherwise

Dummy variable indicating that target is located in Europe $=1$; $0=$ otherwise

Dummy variable indicating that target is located in Asia $=1$; $0=$ otherwise 


\section{Results and Discussion}

Table 3 reports the descriptive statistics and correlations. A number of interesting observations are worth a comment. Mean of formal institutional distance between home and host countries is 6.4418 , suggesting that the bulk of these cross-border M\&As took place in countries with suggesting significant institutional distance in relation with China. The mean of state ownership of 57.8 percent in the acquisitions suggests that on the average the government ownership constitutes a majority stake in most of the firms engaged in CBM\&As. The log of the average size in terms of deal size and acquiring firm size are 2.0326 and 12.530 billion respectively indicating that the deals and firms involved are large ones. All the correlation are fairly low, and variance inflation factor scores are well within the cut-off point of 10 as recommended by Neter, Wasserman, and Kutner (1985). Multicollinearity appears not to be a problem in this study. 
Table 3. Summary Statistics and Pearson correlation Matrix of dependent and independent variables

\begin{tabular}{|c|c|c|c|c|c|c|c|c|c|c|c|c|c|c|c|c|c|}
\hline Variables & MEAN & SD & $\mathbf{A}$ & B & $\mathrm{C}$ & D & $E$ & $\mathrm{~F}$ & $\mathbf{G}$ & $\mathrm{H}$ & $\mathrm{I}$ & $\mathrm{J}$ & $\mathrm{K}$ & $\mathrm{L}$ & $M$ & 0 & \\
\hline A. CAR_-5, 5 & 0.6695 & .487 & 1.00 & & & & & & & & & & & & & & \\
\hline B. FInstDis & 6.4418 & 0.2631 & .030 & 1.00 & & & & & & & & & & & & & \\
\hline C. StateOwn & 0.578 & 0.1447 & $\begin{array}{l}.137^{* *} \\
*\end{array}$ & $.190^{* * *}$ & 1.00 & & & & & & & & & & & & \\
\hline D. ExRate & 0.89 & 0.318 & $.076^{*}$ & $.585^{* * *}$ & $-.158^{* *}$ & 1.00 & & & & & & & & & & & \\
\hline E. ClnstDis & 0.3277 & 0.0042 & .010 & $.172^{* *}$ & -.072 & $.184^{* * *}$ & 1.00 & & & & & & & & & & \\
\hline F. Sector1 & 0.34 & 0.474 & $-.086 * *$ & .024 & .081 & .035 & $.147^{* *}$ & 1.00 & & & & & & & & & \\
\hline G. Sector2 & 0.13 & 0.332 & -.044 & $.095^{* *}$ & -.050 & $.138^{* * *}$ & -.043 & .030 & 1.00 & & & & & & & & \\
\hline H. PriorSec & 0.40 & 0.490 & $-.018^{*}$ & -.017 & .007 & $.075 *$ & .119 & $.427^{* * *}$ & $.455^{* * *}$ & 1.00 & & & & & & & \\
\hline I. Experience & 0.306 & 0.669 & -.022 & -.017 & .043 & $-.089 *$ & .022 & .040 & -.007 & .007 & 1.00 & & & & & & \\
\hline J. CashHld & 17.23 & 13.15 & -.035 & $.183^{* * *}$ & -.049 & $.121^{* * *}$ & $.118^{* *}$ & .067 & -.024 & .063 & .019 & 1.00 & & & & & \\
\hline K. Relatedness & 0.38 & 0.486 & -.000 & .031 & .036 & .070 & $.202^{* *}$ & $.273^{* * *}$ & .021 & $.263^{* * *}$ & .041 & .043 & 1.00 & & & & \\
\hline L. DealSize & 2.033 & 0.2174 & .085 & .056 & -.132 & .003 & -.059 & -.011 & .012 & .000 & .081 & .003 & .045 & 1.00 & & & \\
\hline N.Asia & 0.63 & 0.482 & .004 & $.137^{* * *}$ & $.109 * *$ & $-.116^{* *}$ & $.480^{* *}$ & $.100^{* *}$ & -.019 & $-.091^{*}$ & .003 & .017 & -.045 & $-.114^{*}$ & $.197^{* * *}$ & 1.00 & \\
\hline O. N.America & 0.11 & 0.317 & .040 & .002 & -.035 & -.043 & $.217^{* *}$ & .027 & .007 & .049 & .081 & -.056 & .091 & .030 & .066 & $.472^{* * *}$ & 1.00 \\
\hline P. Europe & 0.16 & .368 & .006 & $.122^{* * *}$ & .063 & $.115^{* *}$ & $.408^{* *}$ & $.158^{* * *}$ & -.026 & .073 & -.081 & .023 & .041 & .062 & $.136^{* * *}$ & $.575^{* * * *}$ & $.353^{* * *}$ \\
\hline
\end{tabular}

Notes: No. of sample: $468 ;{ }^{*} \mathrm{p}<0.1 ; * * \mathrm{p}<0.05 ; * * * \mathrm{p}<0.01$ 
Table 4A reports the standardized average abnormal returns (SAARs) and standardized cumulative abnormal returns (SCARs) for a sample of 468 Chinese cross-border M\&As. The average abnormal return for event window $(-5,5)$ shows that the Chinese acquirers create a positive and significant value in the 5 days following the announcement. The SAARs on the announcement day is $0.1503 \%$ and is statistically significant at $1 \%$ level. The SAARs on 1 to 5 days are $0.0888 \%, 0.1190 \%$, $0.1772 \%, 0.0915 \%$ and $0.0766 \%$ and all of them are statistically significant. The result shown in Table indicates that the Chinese acquirers engaged in CBM\&As experienced positive wealth gains in the short term. The significant daily return on day $-1(0.2380 \%)$, day $-3(0.1061 \%)$ and day -5 (0.1533) may result from information leakage before the announcement.

Table 4: Standardized Average Abnormal Returns (SAARs) and Standardized Cumulative Abnormal Returns (SCARs) of CBM\&As by Chinese Acquirers

\begin{tabular}{llll}
\hline A. Event Days & SAARs & Z-statistic & p-value \\
\hline $\mathbf{- 5}$ & 0.1533 & 3.3033 & $0.0010^{* * *}$ \\
$\mathbf{- 4}$ & -0.0046 & -0.0983 & 0.9217 \\
$\mathbf{- 3}$ & 0.1061 & 2.2874 & $0.0222^{* *}$ \\
$\mathbf{- 2}$ & 0.0711 & 1.5315 & 0.1256 \\
$\mathbf{- 1}$ & 0.2380 & 5.1282 & $0.0000^{* * *}$ \\
$\mathbf{0}$ & 0.1503 & 3.2394 & $0.0012^{* * *}$ \\
$\mathbf{1}$ & 0.0888 & 1.9143 & $0.0556^{*}$ \\
$\mathbf{2}$ & 0.1190 & 2.5644 & $0.0103^{* *}$ \\
$\mathbf{3}$ & 0.1772 & 3.8191 & $0.0001^{* * *}$ \\
$\mathbf{4}$ & 0.0915 & 1.9724 & $0.0486^{* *}$ \\
$\mathbf{5}$ & 0.0766 & 1.6516 & $0.0986^{*}$ \\
\hline
\end{tabular}

\begin{tabular}{llll} 
B. Event Window & \multicolumn{1}{c}{ SCAR $(\%)$} & Z-statistic & p-value \\
\cline { 2 - 3 } CAR $(-\mathbf{1 0 , 1 0})$ & 1.5210 & 6.4780 & $9.29-11^{* * *}$ \\
CAR $(-\mathbf{5 , 5 )}$ & 1.2674 & 6.6806 & $2.38 \mathrm{E}-11^{* * *}$ \\
CAR $(\mathbf{- 2 , 2 )}$ & 0.6671 & 5.5508 & $2.84 \mathrm{E}-08^{* * *}$ \\
CAR $(\mathbf{- 1 , 3 )}$ & 0.7733 & 6.2135 & $2.18 \mathrm{E}-10^{* * *}$ \\
CAR $(\mathbf{- 1 , 1 )}$ & 0.4771 & 5.1280 & $2.93 \mathrm{E}-07 * * *$
\end{tabular}

Notes: $* * *, * *$ and $*$ indicate statistical significance at the levels of $1 \%, 5 \%, 10 \%$ respectively. The table resents the daily standardized abnormal returns and standardized cumulative abnormal returns of 468 cross-border M\&As transactions by Chinese firms during the period 1998-2011. 
Table 4.B presents the standardized cumulative abnormal returns (SCARs) for Chinese acquirers for five different windows which are $(-10,10) ;(-5,5) ;(-2,2) ;(-1,3)$ and $(-1,1)$. For all the 5 windows, the results show that announcement of CBM\&As by Chinese firms create value for Chinese acquirers. Positive returns for all the 5 event windows range from $0.4771 \%$ to 1.5210 and all the returns are statistically significant at $1 \%$ level. Overall, the positive responses indicate that investors regard CBM\&As by Chinese firms as value-creating strategies. This result is consistent with the similar findings by Boateng et al. (2008) and Gibbi et al. (2010) who find that CBM\&As by Chinese and Indian firms respectively create wealth of the acquirers. However, the results are at variance with the conclusions drawn by Click and Harrison (2000) and Aybar and Ficici (2009).

In order to test the impact of state ownership and institutional factors on the short-term firm value of Chinese cross-border M\&As, we carried out multiple regression of SCARs on the explanatory and control variables. Table 5 reports the cross-sectional regression results regarding the impacts of state ownership and institutional variables on Chinese acquirers' SCARs. Across the four regression models (1-4), the state ownership and institutional variables have results which are highly significant. The $F$-values of the four regressions are statistically highly significant. The adjusted $\mathrm{R}^{2}$ range from $9.9 \%$ to $11.3 \%$, suggesting that, the regression procedure explains the variation in the change in firm value of Chinese acquirers. The total amount of variation explained by the model appears reasonable and compares favourably to other CBM\&A studies, such as Gubbi et al., 2010; Kiymaz, (2004) who obtained an overall Adjusted R square ranging between $4 \%$ and $12 \%$ for their studies of acquirer and target firms' value for CBM\&As. The coefficient of the three variables, state ownership, formal institutional distance and exchange rate reforms in models 1 to 4 are significantly positive, indicating that the Chinese government and institutions play a significant role in the value creation of Chinese acquirers. The results provide support for hypotheses 1, 2 and 3. Regarding the informal institutional (cultural) distance, the results indicate that the coefficient is positive and but not statistically significant. Hypothesis 4 is therefore unsupported. The results that 
state ownership influences the value creation of the Chinese acquiring firms may be explained by the fact that Chinese acquirers with large state ownership stake appear to enjoy some degree of soft budget constraints and other preferential treatment despite the enterprise reforms over the past two decades. This result appears surprising in that a number of researchers such as Chen and Young (2010) argue that Chinese firms with dominant state ownership tend to pursue political objectives such as resource seeking rather than shareholder value and financial motives. Another important finding relates to the impact of the liberalisation of the currency approval system on firm value of Chinese acquirers. The results suggest that decentralising the currency approval system on outward investment appears beneficial to Chinese firms engaged in international acquisitions. The results support the notion that liberalising the currency approval procedures reduces bureaucracy and the costs of doing business, thereby generating positive wealth effects when acquisitions are announced. The results of formal institutional distance support our contention that abnormal returns accruing to the shareholder of the acquiring firms tend to increase with the level of institutional development of host country relative to China, reflecting the availability of higher-quality complementary resources and capability. The positive coefficient of culture distance across the four models suggests that the informal institutions such as norms, beliefs and values do not exert a statistically significant influence on value creation of Chinese acquirers. It was expected that the cultural distance between the China and target countries would be high leading to high transaction costs and lower firm value but this appears not to be the case. The results may be explained by the extent to which China has bridged the gap between other foreign countries due to the fact that most of the managers in these firms are Western educated Chinese with deep understanding of the informal institutions in western countries hence the variable being positive but insignificant. Technological advancement may have also played a big role in bridging the cultural distance between China and the rest of the world. The results for the control variables suggest that sector 1 representing manufacturing, priority sector and firm relatedness have positive and significant influence on Chinese acquiring firm value with the 
rest of the variables indicating no significant influence. The positive coefficient of the priority sector variable indicates a positive and significant relationship between the state-backed sectors and wealth gains. This finding is interesting suggesting that, Chinese government through its investment policy framework relentlessly pursue certain long-term objectives to help Chinese firms acquire the resources they lack and thereby create value for these acquirers. The result is consistent with the point made by Rui and Yip (2008) who argue that, Chinese firms strategically use CBM\&As to achieve specific goals, such as acquiring strategic resources and capabilities to offset their competitive weaknesses through the use of government support and other incentives and minimisation of institutional constraints. Conforming to the state-directed policy to acquire strategic assets therefore helps these firms to gain legitimacy, social and financial support from state, which, in turn, leads to maximisation of shareholder value as reflected in share prices. 
Table 5:Cross-sectional regression result: State Ownership, Institutions \& Acquirers' Returns

\begin{tabular}{|c|c|c|c|c|}
\hline Variables & Model 1 & Model 2 & Model 3 & Model 4 \\
\hline Constant & $\begin{array}{l}-8.155 \\
(-1.184)^{*}\end{array}$ & $\begin{array}{c}-2.810 \\
(-0.255)\end{array}$ & $\begin{array}{c}-1.941 \\
(-0.181)\end{array}$ & $\begin{array}{l}-1.425 \\
(-0.120)\end{array}$ \\
\hline \multicolumn{5}{|l|}{$\begin{array}{l}\text { State Ownership \& } \\
\text { Institutional Variables }\end{array}$} \\
\hline State Ownership & $\begin{array}{l}0.255 \\
(4.679) * * *\end{array}$ & $\begin{array}{l}0.255 \\
(4.634)^{* *}\end{array}$ & $\begin{array}{l}0.259 \\
(4.649) * * *\end{array}$ & $\begin{array}{l}0.251 \\
(4.467)^{* * * *}\end{array}$ \\
\hline Cultural Distance & $\begin{array}{c}0.082 \\
(1.464)\end{array}$ & $\begin{array}{c}0.088 \\
(1.557)\end{array}$ & $\begin{array}{l}0.058 \\
(1.010)^{* * *}\end{array}$ & $\begin{array}{l}0.059 \\
(1.045)^{* * *}\end{array}$ \\
\hline Formal Inst Distance & $\begin{array}{l}0.141 \\
(2.570) * * *\end{array}$ & $\begin{array}{l}0.124 \\
(2.214)^{* *}\end{array}$ & $\begin{array}{l}0.138 \\
(2.419)^{* *}\end{array}$ & $\begin{array}{l}0.131 \\
(2.306)^{* *}\end{array}$ \\
\hline Exchange Rate Reforms & $\begin{array}{l}0.180 \\
(3.272) * * *\end{array}$ & $\begin{array}{l}0.167 \\
(2.990) * * *\end{array}$ & $\begin{array}{l}0.170 \\
(2.978)^{* * *}\end{array}$ & $\begin{array}{l}0.166 \\
(2.907) * *\end{array}$ \\
\hline \multicolumn{5}{|l|}{ Control Variables: } \\
\hline Sector 1 & & $\begin{array}{c}0.093 \\
(1.626)^{*}\end{array}$ & $\begin{array}{c}0.092 \\
(1.555)^{*}\end{array}$ & - \\
\hline Sector 2 & & $\begin{array}{c}-0.012 \\
(-0.222)\end{array}$ & - & - \\
\hline Priority Sector & & & & $\begin{array}{l}0.103 \\
(1.745)^{* *}\end{array}$ \\
\hline Prior Experience & & & $\begin{array}{c}0.024 \\
(0.416)\end{array}$ & $\begin{array}{c}0.026 \\
(0.464)\end{array}$ \\
\hline CashHld & & $\begin{array}{c}-0.026 \\
(-0.047)\end{array}$ & $\begin{array}{c}-0.028 \\
(-0.491)\end{array}$ & $\begin{array}{l}-0.027 \\
(-0.470)\end{array}$ \\
\hline Relatedness & & $\begin{array}{c}0.074 \\
(1.293)^{*}\end{array}$ & $\begin{array}{c}0.098 \\
(1.671)^{*}\end{array}$ & $\begin{array}{l}0.103 \\
(1.758)^{*}\end{array}$ \\
\hline DSize & & $\begin{array}{c}0.066 \\
(1.195)\end{array}$ & $\begin{array}{c}0.062 \\
(1.093)\end{array}$ & $\begin{array}{c}0.065 \\
(1.157)\end{array}$ \\
\hline LAcqSize & & $\begin{array}{l}-0.057 \\
(-0.998)\end{array}$ & $\begin{array}{l}--0.069 \\
(-1.175)\end{array}$ & $\begin{array}{l}-0.068 \\
(-.1 .170)\end{array}$ \\
\hline North America & & & $\begin{array}{c}-0.051 \\
(-0.779)\end{array}$ & $\begin{array}{l}-0.052 \\
(-0.900)\end{array}$ \\
\hline Europe & & & $\begin{array}{c}-0.047 \\
(-0.594)\end{array}$ & $\begin{array}{c}-0.047 \\
(-0.820)\end{array}$ \\
\hline Asia & & & $\begin{array}{c}-0.014 \\
(-0.166)\end{array}$ & $\begin{array}{l}- \\
-\end{array}$ \\
\hline $\mathrm{R}^{2}$ & 0.108 & 0.13 .2 & 0.148 & 0.150 \\
\hline Adjusted R² & 0.099 & 0.103 & 0.108 & 0.113 \\
\hline F-value & $9.767 * * *$ & $4.520 * * *$ & $3.692 * * *$ & $4.073 * * *$ \\
\hline
\end{tabular}

Notes: 1.Following the work of Kiymaz (2004), we used standardised cumulative Abnormal Returns (SCAR) for the $(-5,5)$ period as a dependent variable.

2. $* \mathrm{P}<0.1 ; * * \mathrm{P}<0.05 ; * * * \mathrm{P}<0.01$

3. Sector $1=$ manufacturing; Sector $2=$ Primary/Resources 


\section{Robustness Tests}

To check the robustness of our models, we employed several additional specifications to rule out alternative explanations. Table 6 summarises the analysis for the sake of readability and brevity.

Table 6: Additional Analysis and Robustness Tests

\begin{tabular}{lllc}
\hline \hline Issue & Test performed & Specification & Findings \\
$\begin{array}{l}\text { Inter-temporal variation } \\
\begin{array}{l}\text { in abnormal gains to } \\
\text { shareholders (McNamara, }\end{array}\end{array}$ & $\begin{array}{l}\text { Split sample event } \\
\text { study test }\end{array}$ & $\begin{array}{l}\text { Data relating to the } \\
1998-2004 \text { (first-half) } \\
\text { and data relating to the }\end{array}$ & $\begin{array}{c}\text { Mean abnorma } \\
\text { returns in the 1st } \\
\text { half }(\mathrm{N}=84) \text { and }\end{array}$ \\
& $2005-2011$ (second half) & $\begin{array}{c}2^{\text {nd }} \text { half }(\mathrm{N}=384) \\
\text { are both positive } \\
\text { and significant }\end{array}$
\end{tabular}

Structural changes caused Chow test of by changes in forex approval differences system CBM\&As

Efficiency of information Event study tests Dissemination in the stock Market announcement (Miller, window periods Li, Eden \& Hitt, 2008)

Self-selection of advanced market targets by Outperformers

Abnormal gains SOEs versus non-SOEs

Priority Sectors and abnormal gains
Test of difference (t-test)

Test of differences (t-test \& $\mathrm{Chi}^{2}$ test) with alternate

Differences of mean test in the absence of event for firms making Developed/developing Market acquisitions

data pertaining to 1998 June 2006 and data pertaining to July 2006 - 2011 4-, 7-, and 11-day period
as alternatives
No significant quantitative difference observed in the parameters between two periods

Excess of "expected" No significant normal returns over the difference actual market returns in the event window SCARs (-5,5; -2,2, -1,3) Significant event windows; SOEs differences between Versus non-SOEs SOEs and non-SOEs in all event windows

SCARs $(-5,5 ;-2,2,-1,3)$ Statistically and event windows positive significant differences between priority sector and non-priority sector in all event windows 


\subsection{Conclusion}

This study has investigated the value creation implications of CBM\&As by Chinese acquirers during the 1998-2011 time frame. Using a sample of 468 acquisition announcements by Chinese firms involving targets from the North America., Europe and Asia, this paper makes significant contributions on two fronts. First, this study has implications for the mergers and acquisition literature in that evidence on CBM\&As as a value-accretive strategy is mixed and inconclusive (Reuer, Shenkar and Ragozzino, 2004, Seth et al., 2002; Shimizu et al., 2004; Markides and Ittner, 1994; Morck and Yeung, 1991; Moeller and Schlingemann, 2005). King et al. (2005:196) suggest that prior studies have failed to identify contextual conditions under which acquisitions create value for acquiring firms. We find evidence of positive abnormal returns for Chinese acquirers and identify the contextual factors under which CBM\&As create value. Our findings indicate that the average abnormal returns for Chinese bidders range from $0.4771 \%$ - $1.5210 \%$ over the 10-day event window, suggesting that equity markets react positively to acquisition announcements and that Chinese firms are perceived, on average, to create value for shareholders.The cross-sectional analysis results indicate that value creation through acquisitions by Chinese acquiring firms is influenced by the formal institutional distance, reforms in exchange rate approval systems and state ownership suggesting that governments and institutions play a decisive role in CBM\&A value creation. The implication here is that specific reforms, such as easing restrictions on currency for outward investments and state ownership improve firm value. We therefore suggest that the government should take additional steps to further reduce other restrictions on outward investments. In contrast, despite our expectation of negative impact of informal institutional distance on standardized cumulative abnormal returns, we find the results to be positive but not significant. Another significant finding of this study is that Chinese firms making investment in sectors considered strategic by Chinese government tend to create value for acquirers. This supports the contention that emerging country governments do not only shape international expansion strategies 
of firms but also provide opportunities for significant value-creating activities, which correlate positively with market expectations. Another contribution is that, this study adds to the growing stream of literature on emerging economy firms by empirically testing the theoretical arguments relating to the institutional theory and firm value. Our study contributes some important insights to how national governments and institutional pressures on emerging economy firms to expand can also lead to value creation.

While our research constitutes an important attempt to explore international expansion and value creation utilising framework, its limitation should be noted. Although, the event study methodology has wide application in finance, it is pertinent to point out that, it is based on the assumption that stock markets are semi-strong form under efficient market hypothesis. Hence, the results should be interpreted with caution. The event study reflects the market evaluation of complex, and in some cases infrequent, strategic initiatives. It may be possible that the value implications of such complex strategic ventures are not fully understood by the market participants and may be prone to heuristic biases.

\section{References:}

Ali-Yrkko, J. (2002) Mergers and acquisitions: Reasons and Results, Discussion paper series, No. 792, The Research Institute of the Finnish Economy (ETLA).

Ang, S. \& Michailova, S. (2008). Institutional explanations of cross-border alliance modes: The case of emerging economies firms, Management International Review, 551-576.

Aybar, B. \& Ficici, A. (2009). Cross-border acquisitions and firm value: An analysis of emergingmarket multinationals, Journal of International Business Studies, 40, 1317-1338.

Behrman, J.N. \& Rondinelli, D.A. (2000). The transition to market-oriented systems in Central and Eastern Europe: lessons for private enterprise development, Global Focus, Journal of International Business, Economics and Social Policy, 11, 1-33.

Berry, H. (2006). Leaders, laggards and the pursuit of foreign knowledge, Strategic Management Journal, 27, 151-168. 
Blanchard, O. and Shleifer, A. (2001). Federalism with and without political centralization: China versus Russia, IMF staff papers, 48, special issue, 171-179.

Boateng, A., Wang, Q. \& Yang, T.L. (2008). Cross-border M\&As by Chinese firms: An analysis of strategic motives and firm value, Thunderbird International Business Review, 50, 4, 259270.

Boddewyn, J. \& Brewer, T. (1994). International business political behaviour: New theoretical directions, Academy of Management Review, 19, 1, 119-143.

Brunetti, A. \& Weder, B. (1998). Investment and institutional uncertainty: A comparative study of different uncertainty measures, Weltwirtschaftliches Arichiv, CXXXI, 513-533.

Buckley, P.J., Clegg, L.J., Cross, A.R., Liu, X., Voss, H. \& Zheng, P. (2007). The determinants of Chinese outward foreign direct investment, Journal of International Business Studies, 38, 4, 499-518.

Cai, K.G. (1999). Outward foreign direct investment: A novel dimension of China's integration into the regional and global economy, China Quarterly, 160, December, 856-880.

Campa, J.M. \& Kedia, S. (2002). Explaining the diversification discount, Journal of Finance, 56, 1731-1762.

Cartwright, S. \& Cooper, C.L. (1993). The role of culture compatibility in successful organizational marriage, Academy of Management Executive, 7, 2, 57-70.

Chan, C.M., Isobe, T. \& Makino, S. (2008). Which country matters? Institutional development and foreign affiliate firm value, Strategic Management Journal, 29, 11, 1179-1205.

Chen, Y.Y. \& Young, M.N. (2010). Cross-border mergers and acquisitions by Chinese listed companies: A principle-principle perspective, Asia Pacific Journal of Management, 27, 523-539.

Chen, Y.Y. \& Young, M.N. (2010). Cross-border mergers and acquisitions by Chinese listed companies: A principle-principle perspective, Asia Pacific Journal of Management, 27, 523-539.

Child, J. \& Rodrigues, S.B. (2005). The internationalization of Chinese firms: A case for theoretical extension, Management and Organization Review, 1, 3, 381-410.

Cui, L. \& Jiang, F. (2012). State ownership effect on firms? FDI ownership decisions under institutional pressure: a study of Chinese outward investing firms, Journal of International Business Studies, 43, 3, 264-284.

Datta, D.K, \& Puia, G. (1995). Cross-border acquisitions: An examination of the influence of related and cultural fit on shareholders' value creation in US acquiring firms, Management International Review, 35, 337-359.

Deng, P. (2010). What determines firm value of cross-border M\&As by Chinese firms? An absorptive capacity perspective, Thunderbird International Business, 52, 6, 509-524.

DiMaggio, P.J. \& Powell, W.W. (1983). The iron cage revisited: institutional isomorphism and collective rationality in organization fields, American Sociological Review, 48, 147-160. 
Fligstein, N. (1996). Markets as politics: A political-culture approach to market institutions, American Sociological Review, 64, 656-673.

Geringer, J.M., Beamish, P.W. \& daCosta, R.C. (1989). Diversification strategy and internationalization: Implications for MNE firm value, Strategic Management Journal, 10, 109-119.

Guariglia, A., Liu, X. \& Song, L. (2011). Internal finance and growth: Macroeconometric evidence on Chinese firms, Journal of Development Economics, 96, 1, 79-94.

Gubbi, S., Aulakh, P., Ray, S., Sarkar, M.B. \& Chittoor, R. (2010). Do international acquisitions by emerging economy firms create shareholder value? The case of Indian firms, Journal of International Business Studies, 41, 397-418.

Haspeslagh, P.C. \& Jemison, D.B. (1991). Managing Acquisitions: Creating Value through Corporate Renewal, Free Press, NY.

Hitt, M.A., Ahlstrom, D., Dacin, M.T., Levitas, E. \& Svobodina, L. (2004). The institutional effects on strategic alliance partner selection in transition economies: China vs. Russia, Organization Science, 15, 2, 173-185.

Hofstede, G. (1980). Cultures Consequences: International Differences in Work-related Values, Sage, Beverly Hills.

Hoskisson, R.E., Eden, L., Lau, C.M. \& Wright, M. (2000). Strategy in emerging economies, Academy of Management Journal, 43, 3, 249-267.

Jensen, M.C. (1986). Agency cost of free cash flow, corporate finance and takeovers, The American Economic Review, 76, 2, 323-329.

King, R., Dalton, R., Daily, M. \& Covin, J. (2004). Meta-analyses of post-acquisition firm value: Indicators of unidentified moderators, Strategic Management Journal, 25, 187-200.

Kofele-Kale, N. (1992). The political economy of Foreign Direct Investment: A framework for analysing investment laws and regulations in developing countries, Law and Policy in international Business, 23, 619-671.

Kogut, B. \& Singh, H. (1988). The effect of national culture on the choice of entry mode, Journal of International Business Studies, 19, 3, 411-432.

Lau, C.M., Fan, D.K.K., Young, M.N. \& Wu, S. (2007). Corporate governance effectiveness during institutional transition, International Business Review, 16, 425-448.

Leone, R. (1986). Who Profits-Winners, Losers and Government Regulations, Basic Books, New York.

Lin, H.C.M \& Bo, H. (2012). State ownership and financial constraints on investment of Chinese listed firms: New Evidence, European Journal of Finance, 18, 6, 497-513.

Luo, Y. \& Park, S.H. (2001). Strategic alignment and firm value of market-seeking MNCs in China, Strategic Management Journal, 22, 2, 141-155.

Luo, Y. (2003). Industrial dynamics and managerial networking in an emerging market: the case of China, Strategic Management Journal, 24, 13, 1315-1327. 
Markides, C.C. and Itnner, C.D. (1994). Shareholder benefits from corporate international diversification, Evidence from US international acquisitions, Journal of International Business Studies, 25 (2): 343-366.

Meyer, K. E., Estrin, S., Bhaumik, S. K., \& Peng, M. W. 2009. Institutions, resources, and entry strategies in emerging economies, Strategic Management Journal, 30(1): 61-80.

McGee, J., Thomas, H. \& Wilson, D. (2008), Strategy: Analysis and Practice, McGraw-Hill Higher Education, New York.

McWilliams, A. \& Siegel, D. (1997). Event studies in management research: Theoretical and empirical issues, Academy of Management Journal, 40, 3, 626-657.

Moeller, S.B., Schlingemann, F.P. \& Stulz, R.M. (2004). Firm size and the gains from acquisitions, Journal of Financial Economics, 73, 201-228.

Moeller, S.B., Schlingemann, F.P. \& Stulz, R.M. (2004). Firm size and the gains from acquisitions, Journal of Financial Economics, 73, 201-228.

Morck, R., Yeung, B. \& Zhao, M. (2008). Perspectives on China's outward foreign direct investment, Journal of International Business Studies, 39, 3, 337-350.

Morosini, P., Shane, S. \& Singh, H. (1998). National culture distance and cross-border acquisition firm value, Journal of International Business Studies, 29, 1, 137-158.

North, D.C. (1990). Institutions, Institutional Change and Economic Firm value, Cambridge University Press, Cambridge.

Oliver, C. (1991). Strategic responses to institutional process, Academy of Management Review, 16, 145-179.

Peng, M.W. (2002). Towards an institution-based view of business strategy, Asia Pacific Journal of Management, 19, 251-267.

Peng, M.W. (2002). Towards an institution-based view of business strategy, Asia Pacific Journal of Management, 19, 251-267.

Peng, M.W., Wang, D.Y.L. \& Jiang, Y. (2008). An institution-based view of international business strategy: A focus on emerging economies, Journal of International Business Studies, 39, 920-936.

Peng, P (2010). What determines firm value of Cross-border Mergers and Acquisitions by Chinese companies? An Absorptive capacity perspectives, Thunderbird International Business Review, 52, 6, November/December, pp. 509-524

Poncet, S. Steingress, W. \& Vandenbussche, H. (2010). Financial constraints in China: firm-level evidence, China Economic Review, 21, 3, 411-422.

Porter, M.E. (1990). The Competitive Advantage of Nations, Free Press, MacMillan, New York.

Prabhala, N. (1997). Conditional Methods in Event Studies and an Equilibrium Justification for Standard Event-Study Procedures, The Review of Financial Studies, 10, 1, 1-38. 
Rosenzweig, P.M. and Singh, J.V. (1991). Organizational environments and the multinational enterprise, Academy of Management Review, 16, 2, 340-361.

Rugman, A. \& Li, J. (2007). Will China's multinationals succeed globally or regionally? European Management Journal, 25, 5, 333-343.

Rui, H.C. \& Yip, G.S. (2008). Foreign acquisitions by Chinese firms: A strategic intent perspective, Journal of World Business, vol. 43, 213-226.

Salter, M. S. \& Weinhold, W. A. (1979). Diversification through Acquisition: Strategies for Creating Economic Value, The Free Press, New York.

Salter, M. S. \& Weinhold, W. A. (1979). Diversification through Acquisition: Strategies for Creating Economic Value, The Free Press, New York.

Scott, W.R. (1995). Institutions and Organizations, SAGE, Thousand Oaks, CA.

Scott, W.R. (2002). Organizations and the natural environment: Evolving models, In Organizations, Policy, and the Natural Environment: Institutional and Strategic Perspectives, 453-64, Andrew Hoffman and Marc Ventresca, (ed), Stanford University Press, Stanford, CA.

Shane, S.A. (1992). The effect of culture differences in perceptions of transaction costs on national differences in the preference for licensing, Management International Review, 32, 295-311.

Sharma, D.S. \& Ho, J. (2002). The impact of acquisitions on operating firm value: Some Australian evidence, Journal of Business, Finance \& Accounting, 29, 1\&2, 155-200.

Shleifer, A. \& Vishny, R.W. (1994). Politicians and firms, Quarterly Journal of Economics, 109, 4, 995-1025.

Seth, A., Song, K.P. and Pettit, R.R. (2002). Value Creation and destruction in cross-border acquisitions of US firms, Strategic Management Journal, 23, 10: 921-940.

Spicer, A., McDermott, G.A. \& Kugut, B. (2000). Entrepreneurship and privatization in central Europe: The tenuous balance between destruction and creation, Academy of Management Review, 25, 630-649.

Sudarsanam, S. \& Mahate, A.A. (2003). Glamour acquirers, method of payment and postacquisitions firm value: The UK Evidence, Journal of Business Finance \& Accounting, 30, $1-2,299-342$.

Sun, Q. \& Tong, W.H.S. (2003). China share issue privatization: the extent of success, Journal of Financial Economics, 70, 183-222.

Sun, Q., Tong, W.H.S. \& Tong, J. (2012). How does government ownership affect firm firm value? Evidence from China's privatization experience, Journal of Business Finance and Accounting, 29, 1, 1-27.

Tian, L.H. \& Estrin, S. (2008). Retained state shareholding in Chinese PLCs: Does government ownership always reduce corporate value? Journal of Comparative Economics, 36, 1, 74-89.

Tsui, A.S., Schoonhoven, C.B., Myers, M.W., Lau, C.M. \& Milkovich, G.T. (2004). Organization and Management in the midst of social transformation, The People's Republic of China, Organization Science, 15, 2, 133-144. 
United Nations Conference on Trade and Development (UNCTAD) 2005. World Investment Report 2005, United Nations, NY and Geneva.

United Nations Conference on Trade and Development (UNCTAD) 2012. World Investment Report 2012: Toward a new generation of investment policies, United Nations, NY and Geneva.

Voss, H., Buckley, P.J. \& Cross, A.R. (2010). The impact of home country institutional effects on the internationalization strategy of Chinese firms, Multinational Business Review, 18, 3, 2548.

Walter, C.E. \& Howie, J.T. (2003). Privatizing China: The stock markets and their role in corporate reform, Wiley, Singapore.

Wei, Z., Xie, F. \& Zhang, S. (2005). Ownership structure and firm value in China's privatized firms, Journal of Financial Quantitative Analysis, 40, 87-108.

Williamson, O.E. (1985). The Economic Institutions of Capitalism, The Free Press, New York.

Wong, J. \& Chan, S. (2003). China's outward direct investment: Expanding worldwide, China: An International Journal, 1, 2, 273-301.

Wu, F. \& Sia, Y.H. (2002). China's rising investment in Southeast Asia: Trends and outlook, Journal of Asian Business, 18, 2, 41-61.

Xiao, J. \& Sun, F. (2005). The challenges facing outbound Chinese M\&As, International Financial Law Review, 24, 12, 44-46.

$\mathrm{Xu}$, D. and Shenkar, O. (2002). Institutional distance and the multinational enterprise, The Academy of Management Review, 27, 4, 608-618.

Xu, E. \& Zhang, H. (2008). The impact of state shares on corporate innovation strategy and firm value in China, Asia Pacific Journal of Management, 25, 473-487.

Young, M.N., Peng, M.W., Ahlstrom, D., Bruton, G.D. \& Jiang, Y. (2008). Corporate governance in emerging economies: A review of the principal-principal perspective, Journal of Management Studies, 45, 1, 196-220. 